\title{
Macroeconomic Effects of World Energy and Food Price Shocks in South Asia
}

\author{
Huma Maqsood, Habib Ahmad \\ Foundation University, Rawalpindi \\ Foundation University, Rawalpindi
}

\begin{abstract}
The purpose of the study is to examine the effect of energy and food prices on macroeconomic variables .A Panel of numerous countries including Pakistan, India ,Bangladesh, SriLanka, Bhutan, Nepal, Afghanistan and two other countries like US and Japan over the period of 1982 to 2010 is examined with yearly frequency.Result indicates that macroeconomic variables are highly sensitive to food and oil shocks. Panel regression is applied to investigate the relationship of both.
\end{abstract}

Key words: Food index, energy index, Export, import, inflation, GDP

\section{Introduction:}

Oil plays an important role in human life and is used as an engine in industrials operations, productions, and household sector, similarly energy like electricity is in different ways light for lightning and used in computer etc (Hamilton, 1983, 1996, 2003).High FP create huge crises during 1970s.Economic performance decline with the increase of CP demand and supply are highly affected by high price of food and energy. In support of these extra limitations, appear into the economic theory is given. Regard- less of the economic conditions of the many different economies covered by this study it is assumed.

When oil prices shocks exists there is negative influence on output growth and exchange rate, and absolutely affect inflation and interest rates. With the increase in food prices it helps depreciate real effective exchange (khan, M.A, \& Ahmed 2001).It is argued that the economic characteristics of a country are affected by the external food and oil prices. Although the modern history tells that there is increase in food and oil prices in many last years all over the world which generate poverty. A lot of food cost depends on the raw material cost, transportation cost, imports, exports, government policies, exchange rate, inflation rate etc.There are different ways to affect the economy like with the increase of oil prices we have lesser amount of money to spend food, shelter, clothes and travels (Kumar, 2009, Chukauet al., 2010). Actual wages and high unemployment is affected by turndown the productivity growth .High energy and food prices disturb the economic activities of the world because when prices increase, the wages of the workers do not increase as a result the Government also affected, for the reason that lots of their cost, such as building roads and bridges are higher. In 2006 and 2007 theoretically the financial circumstances, low interest rate help out the increase economic activities and high interest rate decrease the economic activitieswith the increase of both food and oil it affects the budget of the economy. In the economy of Pakistan unenthusiastic and major growth association has been establish. Pakistan is a developing country where food and oil prices increase day by day. This creates shocking affect on the economy of Pakistan.

The data and new methods of investigating are to investigate how to reduce food and energy prices in Pakistan. The fundamental aim of the macroeconomic strategy makers is High and constant economic growth with low inflation rate.High inflation is constantly associated with increased price inconsistency. In dealing with superior inflation which is created with the increases in product prices the monetary policy makers face number of tribulations. Inflation is calculated by food and energy prices. The real output is lower the possible output. There is no extra ability and the economy is working on full employment level .As the actual production becomes equal with the possible production. Researchers discuss that all the macroeconomic variables like inflation ,GDP, unemployment, wages, stock exchange, etc are affected due to increase in food and energy prices in south Asia. There is negative relationship between the macroeconomic presentation and International product prices of oil import countries through the demand-side and supply-side channel.dollar also produces inflationary demands because oil is denominated in U.S. dollars.

From December 2011 to March 2010 the food price increased by 8 percent , and crude oil prices increased by 13 percent internationally. In the 1970s, supply shortfalls are greater as compare to current shortfall.

After the Yom Kippur war 1973 first oil shocks comes, when the organization of petroleum Exporting Countries 'Arab members turned off the taps on roughly 8 percent of the world's oil supply by cutting shipment to the U.S and other Israeli allies. Crude prices spiked, and in 1974 the real GDP had shrunk by 2.5 percent in the U.S. During Iran's revolution the second OPEC oil shock happened and the succeeding war with Iraq. 
During the revolution the crude prices higher sent a signal of Disruptions to Iranian production, almost the North American economy into a recession for the first half of 1980. Little months later on, the world oil production push to off 6 percent in the Iran's war with Iraq. In the spring of 1981, North America began into a double-dip recession. There are many different ways that an oil shock can hurt an economy. Iran and Iraq had been at but collective production from these two countries actually increased by $40 \%$ more the duration of the conflict. According to the Commodity Research Bureau's spot index of foodstuffs, between the start of 2000 and mid-2008, food prices rose by $150 \%$.

The food and oil price crises explained by different methodologies and assumptions for the reduction of poverty.Making new strategies, and policies to reduce the prices of both. Current agriculture foodstuffs use oil in different ways like it is use in chemical sectors, use in machines and equipment for manufacture, and it is also use in transport for to deliver the productivity to the end user.With the increase of food and energy price, economy faces these troubles.

High Unemployment, Liability increases, poor financial condition, reduce economic growth, reduce the value of property, if an individual cannot work so taxes rate low, export restriction, long term supply trouble, modify in demand,low interest rate and reduction in dollar .

From 2002 levels the oil prices had double by 2006.In the same way from rising oil prices to what we would expect. The world bank in February 2011 as a result of food prices increase in 2010 is estimated net increase in the aggravate poverty of 44 million people. World Bank study that oil prices were more important to food prices then numerous other long term price as well as exchange rate, interest rate and income. The Asian Development Bank (march 2011) estimated domestic food price inflation in developing Asiancountries increase by the international food prices. The purchaser can hurt with the increase of prices. lvanic and Martin (2008).

Oil prices constant growing in February 2012.each spring oil prices increase. In 2013, prices started rising in January, reaching on February 13, 2012. There is imperfect shock of food prices can be recorded for India, Korea and Thailand in conditions of manufacturing yield, inflation and interest rate.There are many reasons of Oil prices shocks for international economic slowdown particularly for oil importing countries (Hamilton 1983, Hamilton 1996, Hamilton 2003).

Food price also affect the both importers and exporters of the food. Financially the exporters are in the better positions as compare to importers for the reason that they accumulate the funds from oil and food. The different groups of the countries, estimated rate is most close to primary food in total food consumption. The importers tariffs and other dues are reducing when price of food and petroleum are increase internationally and domestically. The exporters, importers and trade balance are also affected by high price of oil. The economic activities of the importers countries turn down whit the high price of oil. Increases in oil price will have significant impact on global trade pattern. International trade of high income countries is less affected as they are more less oil intensive service based economies. Middle income countries lose more international trade due to their oil based manufacturing economy. Upward countries with imperfect capability receive revenue from Export duties. Export excise can get better conditions of trade; export duties can decrease the household price.

The main objective of the study is to check the impact of world food and energy on import, export, inflation, and GDP. Researcher is desirable on the way to explore the correlation between the effects of world food and oil prices shocks in south Asia and pacific economies. Researcher interpretation these and obtain out the reality. Therefore, the aim of the paper is to show us which of the factors affects significantly to the food and oil prices. Results of this research help the managers in their field work of the project. Research also helps them acquire up to date through the processes and resources implicated in addition to response from the market. This type of information helps in the successful outcome of the project. Energy play a vital role in the human life but at this time energy crises is one of the major issue in Pakistan. Thus, through the results of energy consumption and their impact on oil and food prices, field workers especially managers are able to capture benefit at the same time as taking decisions designed for time-consuming. The researcher will be official for policy makers. It will help them to understand the effect of price rise to the economy of the respective countries.

\section{Literature Review:}

High food and oil prices can affect the living standard of an individual (Bekkers, Brockmeier, Francois, \& Yang, 2013).because of the fact that food is a basic need and its demand is relatively inelastic whereas oil prices can affect prices of most commodities consumed by an individual (Alom, Ward, \& Hu, 2013).

Various factors increase the ranks of the middle class by changing consumption patterns to climate change, increasing food prices, the declining of dollar,etc (Carrasco \& Mukhopadhyay, 2012).Although, a direct relationship also exists between the energy and food prices (Alom, Ward, \& Hu, 2013). Oil and food prices have moved in equivalent. when the prices increase it reduces the purchasing power of private household and it can affect the production process and firms face loss because firms pay wages to labors(Belke \& Dreger, 2013). Both oil and food prices co-move in international market (Dillon \& Barret, 2013).Numerous countries that are oil poor, but healthy established in international financial services are not affected with the increases of oil 
prices. Same as developing countries which have imperfect reserve are not affected by oil prices (Alom, Ward, \& Hu, 2013). Developing countries like India with various natural resources negligibly affected by oil prices shocks due to limited stores of oil. So Indian interest rate show optimistic response to the oil price shocks (Alom, 2011).It is also show relationship among the rate of money increase and the growth rate depend seriously on the elasticity of exchange between money and credit merchandise (Jones \& Manuellib, 1995). There is correlation ship between food and crude oil prices because oil is important factor in the production for food and agricultural products (Bakhat \& Würzburg, 2013) (Bakhat \& Würzburg, 2013).

There is no long-term and short-term association involving energy and food prices. Together in the short and long run foodstuff prices are more exaggerated by oil prices.depressing collision on food prices is generated by high oil prices (Avalos, 2013). Macroeconomic changes have real short-run and long-run effects on the prices of agricultural commodities .The short- and long-run impacts of macro policy could add to price and income instability. There is a strong correlation among energy and commodity prices (Saghaian, 2010).In the short-run copper, food and cultivation raw material are asymmetric to optimistic and pessimistic from the long-run equilibrium (Bakhat \& Würzburg, 2013).There is extraordinary concentration in the correlation between the oil prices and other products (Bakhat \& Würzburg, 2013).

Ethanol promotion policies in the United States produce the association connecting energy and food prices (Avalos, 2013).There is correlation among the rate of escalation of production and the rate of enlarge of the money Supply in an economy (Jones \& Manuellib, 1995).

How oil price effect on the food price of the countries. There is positive relationship between them as the oil price increase the food price also increases.oil prices are another barrier for the growth of economy. In the current years, both oil and food markets are new mutually dependent as compare to past years (Alom, Ward, \& $\mathrm{Hu}, 2011)$.

(Dillon \& Barret, 2013)Explain the relationship of oil and food price and discuss it with the example of maize and also discuss the energy price in international market, domestic market and sub-nation market. Global market has significant relationship to the national market. There is long term equilibrium relationship between global and national market. Global prices send out to national market, with reasonably high rates, but transmission from global market to domestic market is very slow (Bekkers, Brockmeier, Francois, \& Yang, 2013).They investigate that international food prices are transmitted into domestic markets due to different margin effect (Khan \& Ahmed, 2011).Argued that if oil prices increase there is indirect affect on customer's prices. For the reason that oil is use in production while food prices increases there is direct effect of inflation. Because food is consumed directly. When oil prices increases it create bad affect on productivity. It also creates bad affect on wages, service, advertising, promotion, and core inflation, profit and investment (Khan \& Ahmed, 2011).

(Baumeister \& Kilian, 2013) Dillon \& Barret, 2013) communicate there is no proof that food prices increases due to increase the price of energy. He also discuss that the cost of food processing, packing price, transportation and distribution are responsible for higher retail food price. Oil price cannot affect the food price.

High energy prices have increased the costs of transportation and agricultural inputs such as fertilizer and pesticides, making agricultural production more expensive (Saghaian, 2010).Many pundits also agree that oil prices affects food prices in different ways. Some other observers are claiming that oil prices have reflected food prices. A general perception between academics and policymakers is that oil prices increase have been related with the higher food prices.The difference between retail food prices and prices received by former through crops is more important (Baumeister \& Kilian, 2013).No major influence of food and oil prices. Although there is a wide facts of encouraging association involving both of them (Alom, Ward, \& $\mathrm{Hu}, 2011$ ). Fuel market quickly changes due to change in oil market (Dillon \& Barret, 2013). Marketing series affected by crude oil like manufacturing plants, cost of transportation and operating packing houses and this series increase the cost of food (Capehart \& Richardson, 2008). After food prices boost it generate shocking impact on poor rustic households in many developing countries (Freire \& Isgut, 2011). The food and energy prices increase the cost of production for the duration of 2007-2008 which hinder the industrial production and reduce the productivity growth(Khan \& Ahmed, 2011) (Capehart \& Richardson, 2008). Increase in the price of both i.e. food and energy may affect macroeconomic variables like interest rates, inflation rates, exchange rates etc (Abbott, 2009).

Oil and food prices shocks considerably affect the industrial output, short-term interest rate inflation rate, real exchange rate these are the leading source of variation in Pakistan. Through these sources of variation there is conflict between supply-side and demand-side (Khan \& Ahmed, 2011).The major source of macroeconomic fluctuation is, increase in energy and food prices internationally. When commodity prices increases in worldwide .Travels in international commodity price is the main source of business cycle (Khan \& Ahmed, 2011). 
(Ayyoub, Chaudhry, \& Farooq, 2011) Find financial sector of the economy, minimizing fluctuations and fears through reasonable and constant inflation. Which increase the capital formation actions in the country so it creates positive effect on the economy?

Fluctuation in the oil price have bad effect in exchange rate because when local currency is measured on the bases of oil price the impact is much higher as compared to oil price in foreign countries. When oil prices shocks are distinct in restricted currencies there is limited impact to short run and more significant (Cunado, 2005)(Alom, 2011)(Khan \& Ahmed, 2011). Investigate that when oil prices increase it creates negative effect on industrial production growth, exchange rate, and stock prices, and positively affect on inflation and interest rate.

There is no verification of a physically powerful straight connection among production growth $\mathrm{n}$ exchange rate. Moreover observe that there is direct and oblique connection involving GDP increase and exchange rate. Exchange rate policies are frequently responsive and contentious, in upward countries (Akpan \& Atan).Rising food prices are contributing to higher inflation (Brahmbhatt \& Christiaensen, 2008) (Cecchetti \& Moessner, 2008).Through the inflation overall food cost increase and food inflation rate depend on the shareof grain and oilseeds. Inflation creates food more expensive in developing countries. Because food is a much larger part of consumption in daily life .with the inflation any individual cannot save their earnings and wages. so individual goes off not as good as quality of life.Even that the government have reduce the international prices in domestic market (Abbott, 2009)(Dev, 2013) .Balance of payment is also affected by inflation.Inflation is very harmful .if the general price level increase constantly it hurts the economy growth (Ayyoub, Chaudhry, \& Farooq, 2011).In the developing countries the inflation can have negative impact on food security and poverty(Freire \& Isgut, 2011).The economy of Pakistan establish a negative and important inflation growth relationship (Ayyoub, Chaudhry, \& Farooq, 2011) (Cunado, 2005). Inflation enhances the economic growth of the Middle East countries. Sometime it is good for the country growth and to raise the economy .Inflation has its own benefits.They determining short run and long run relationship between two variables. Although south Asian countries like Bangladesh, India, Pakistan, and Sri Lankawishes to reduce their inflation rates and improve the economy growth these countries are under pressure from the worldwide lending agencies likeIMF, the World Bank and ADB. Theinternational lending agencies of the policy advice attemptsto drop off the inflation(Mallik \& Chowdhury, 2001).

Pakistan is facing the stagflation since 2007-2008.staginflation means very little economic growth combined with high prices of the products.Supply-side shocks are the cause of the current stagflation (Khan \& Ahmed, 2011).Higher inflation is the outcome of increase in the growth rate in the money supply (Jones \& Manuellib, 1995).The investmentstock affected by the inflation.Through the mixture of inflation tariff and tax on capital income the administration have to finance a permanent stream of expenditures. when inflation rate increase it means there is reduction in tax on capital income (Jones \& Manuellib, 1995).some Asian countries use different energy production and oil CPI Specifications in order to calculate the of oil prices together inflation and economic growth rate (Cunado, 2005).If the price of the product do not reverse to their preceding level then the temporary inflationary create (Cecchetti \& Moessner, 2008).The policy makers makes the policies about a global food shortage and about inflationary pressures (Baumeister \& Kilian, 2013).Inflation increase in 1970s(Martin, 2009). Raise in food price and rise in inflationis the result of increase in energy power. Thesecond majority crowded state which consists of large number of poor in the world is India. In India the environment and amount of food price inflation has been fewer strict as compare too many other growing countries (Ganguly \& Gulati, 2013). The central objective of the macroeconomic policy makers is high and sustained economic growth with low inflation.High inflation is always linked with increase price inconsistently(Cunado, 2005).product prices rose powerfully in modern years mid-2008, when inflations rate is high in international level (Cecchetti \& Moessner, 2008).

(Alfaro, Chanda, Ozcan, \& Sayekd, 2004) Explain that FDI can give the development hard work of the country for the reason that the position of upward countries changed by the FDI. Countries get help from Agencies, and policies to attract FDI and these policies make mutually, rising nations and developed countries.

In the provisions of market-base financial arrangement and bank-based fiscal arrangement in Australia there is forceful correlation connecting financial development and economic growth .conjugal Economy depends on equally the role of direct financing of the monetary markets and indirect financing of the fiscal markets. Economic growth can get better position through the stock market (Thangavelu, Jiunn, \& James, 2004). Whether food prices are connected with energy prices or not, purchasing authority and the economic development of the country is effected by the high prices of the product (Bakhat \& Würzburg, 2013). Since the 1980s sets of policies trim down countrywide and worldwide economic welfare, and contribute to international inequity and scarcity (Valenzuela, van, \& Anderson, 2009).The elevated economic growth spoil through the lofty food and fuel pieces (Ganguly \& Gulati, 2013). 
(Bekkers, Brockmeier, Francois, \& Yang, 2013) (Dev, 2013) The worldwide crises which started in 2008 on the behalf of this explosion product market to rising price insecurity, food security, poverty reduction, and higher inflation assumption procedures have been responsible.

In the same way instability in food price increase a lot in 2010 and 2011 but less at initial. Higher food prices are precious for the net seller, for the reason that the no of net buyer are more than net seller (Belke \& Dreger, 2013). Examiner describe the commodity crisis of 2007/2008 and 2010/2011 underscores the weakness of the worldwide food structure to shocks from miscellaneous sources (Bekkers, Brockmeier, Francois, \& Yang, 2013). Oil price deeply increase after World War 2 (Cunado, 2005). High oil prices in 1973-74 and 1981-82 was linked with an economic explosion in oil- exporting countries and downturn in oil-buying countries. Asian financial crises did not extend globally in 1997-1998. In December 2007, with the increase of food and fuel prices recession began in the United States (Martin, 2009). Most important sectors like building, financial services, industrialized, and travel-related service affected during the recession of 2008-2009. In the US Employment in fiscal services is also declining. In 1970s oil prices shocks generate unenthusiastic impact on balance of payment. Theresearcher explains with the increase of food and energy prices inflation rates rose, exportsshrinks, and the economy face recession. In view of the current account scarcity and the economy's experience to Capital flight balance of payments and exchange rate are especially in danger (Wakeford, 2006). The next oil terror in 1979-80 is linked with Iranian revolution in the manufacturing countries and a new bonus in the oil exporting states. On the other hand demand for oil reducesrapidly (Martin, 2009). India 2008 to overcome the global financial crisis, expansionary fiscal and monetary policies depended on the cost of such production, the currency in circulation and thus import prices and inflation affect exchange rates both domestic as well as external factors (Sohrabji, 2011).There was extensive shortage, hunger, and agriculture had been disused by equally national governments of developing countries and international donors in the world before crises. Morethan 75 million peoples are now hungry in 2008. In upward countries the International Monetary Fund (IMF, 2008). highlights the negative macroeconomic consequences. The international agricultural commodity prices had began to increase in mid-2006, getting extremely high levels at their highest point in mid2008. Researcher also describe the Price variations for other commodities and inputs to agriculture. particularly fertilizer and energy have been at least as unstable.It is estimated that the trends of demand growing earlier than supply.both national governments of developing countries and the international contributor community have responded for this food crisis (Abbott, 2009)(Baumeister \& Kilian, 2013). 2008 and 2011 high food prices crises pay attention to the shock on poverty macroeconomic stability food insecurity in developing world (Dillona \& Barrett, 2013). After May 2006 the former who received real price from their products such as corn, rice, wheat, and soybeans cab be prepared to accept with the modestincrease in the real price of food. It is observed that the retail cost of these form of products are very small (Baumeister \& Kilian, 2013). For increasing yield of small farmers there are many institutions and opportunities in technology (Dev, 2013). Everything is interconnected when energy and petroleum prices increases it will have huge shock on agriculture sector.There is no straight and indirect impact of oil prices on cultivation yield prices (Alom, Ward, \& Hu, 2011). Indian farming and food strategy did not modify due to change in international food price (Ganguly \& Gulati, 2013). Agriculture sector play an important role in the shape of export (Hanson, Robinson, \& Schluter, 1993). The rise in the new biofuel agribusinesses have increase the relationship of energy market and agriculture .The bigger demand for corn and constant growth of biofuel industries is most significant for the cultivator and agribusinesses (Saghaian, 2010). When the international food prices increase it create major hardshiptoo many developing countries in south Asia in 2007 and 2008 (Abbott, 2009), (Dev, 2013). Suddenly the international prices started reducing in the second half of the 2008 (Ganguly \& Gulati, 2013). In 2010 rise in food prices are not the reason of scarcity in any countries (Freire \& Isgut, 2011). Regional and international cooperation policy combined with poor safety and strengthen food security is good with domestic policies; these policies are more climate-friendly source of energy to promote (Brahmbhatt \& Christiaensen, 2008). Low income and net importing countries are poorly affected with high prices of both. Accelerating, high and unstable prices can express to increase the poverty and political uncertainty (Belke \& Dreger, 2013). The examiner suggeststhe benefits and cost of organization's food for the purpose of how we eliminate the poverty and make stability in the economy? this may be done by controlling the food prices that are prevailing in the countries it also make a comprise of stable food price and the fluctuating one like stable and control food price prevent farmer and consumer and also prevent the farm level investment (Dawe \& PeterTimmer, 2012). The consumer and the political reason do not face the true market prices of food and fuel commodity in developing countries like Pakistan. So the producer charge high price on their products because they manufacture the products in high cost by using crude oil, fuel and energy etc(Khan \& Ahmed, 2011).

(Charnavoki \& Dolado, 2013) Increase in commodity prices produce a favorable effect on outside balance.increase and decrease in the real energy prices can have vary force full effect on macroeconomic aggregates. The final consumption of world food prices are variesfrom country to country (Bekkers, Brockmeier, Francois, \& Yang, 2013). In the South Asia region the impact of commodity boom from country to country 
with favorable and unfavorable conditions of interchange (Dev, 2013).The different groups of countries, the estimated rate of the total food consumption is most close to the primary food (Bekkers, Brockmeier, Francois, \& Yang, 2013).Harsh political protests invited by high price throughout 2010-11 and 2010-12. The government had being tried to reduce the prices(Ganguly \& Gulati, 2013). Export taxes reduce the household prices of the products. And these taxes improve the public revenue. In small countries WTO system do not contract with the use of control import tariffs and sell overseas taxes (Bouët \& Debucquet, 2010). There are physically influential similarities relating import tariffs and export excise. Due to food crises small countries which are net foodimporting countries can be muscularly injured (Bouët \& Debucquet, 2010). During (2006-2008) the recent food crisis, several upward countries implemented export limitations and export duty.The world price is exaggerated by the export tax in huge country; because a large country is depend more onexport shares (Bouët \& Debucquet, 2010).Oil export countries in the Middle Eastern and North Africa countries would increase the majority of product with the increase of oil prices. Ininternational level the enlarged oil price creates negative impact (Timilsina, 2013).There is indirect funding to manufacturing and processing industries on primary commodities. Developing countries which have limited capacity rely on domestic taxation (Bouët \& Debucquet, 2010). High prices of the products and oil,better for the exporters because they expect to maintain their desire market with high price ,and it is shocking for importers for the reason that they can't afford enough money for purchasing of commodity (Brahmbhatt \& Christiaensen, 2008)(Dev, 2013) (Bouët \& Debucquet, 2010).

(Alom, Ward, \& Hu, 2011)Clarify net food importer's countries with the increase of food prices show the stronger effect on the exporter's countries. There is no difference between the importer and exporters in terms of insecurity of food. FDI plays an important role to exploit the reimbursement of overseas investments .assessor also examinesthe relations between financial market, economic and foreign direct investment (Alfaro, Chanda, Ozcan, \& Sayekd, 2004).

Finally, there is a key irregularity between net exporters and net importers of an agricultural commodity in a situation of foodcrisis. In net food-importing countries when agriculture prices increase internationally it reduces import tariffs and to increase export tariffs in net food-exporting countries. The most important intention of policymaker is escalating exports and decreasing imports (Bouët \& Debucquet, 2010). In 2004 the share of worldwide farm manufacture exported was a little smaller as compare to those reforms since 1980-84, for the reason that of fewer farm export subsidies (Valenzuela, van, \& Anderson, 2009). when the food price increase largely it is also increase the per capita income in emerging economies at that time when temporary supply distraction (Cecchetti \& Moessner, 2008). Export tax increases and tariff reductions (Abbott, 2009). Real exchange rates and the industrial production of developed countries are also affected by the high energy prices (Bakhat \& Würzburg, 2013). Exchange rate and foreign borrowing can adjust by the import and export and also help the govern supports programs. cost of production should rise with the rise in energy prices. When oil purchase from another country theimporter country pays in dollar it means the value of dollar fall dawn (Bakhat \& Würzburg, 2013). The Recent high prices of food are the key factor of the depreciation of the U.S. dollar (Saghaian, 2010). Depreciation of the exchange rate to import prices for domestically produced goods and imported inputs, have an impact on domestic inflation. The exchange rate and the output gap are included in the price of oil (Sohrabji, 2011).The researcher explain that increase in oil prices help turn down economic activities of the oil importers countries (Alom, Ward, \& Hu, 2013). Some upward countries that are net food importers or have a improved location to agricultural markets of high-income countries have unfavorable effect on the global conditions of trade (Valenzuela, van, \& Anderson, 2009). Changes in the trade policies of many countries, domestic taxes and subsidies through changes in domestic food prices are starting to reduce and through administrative measures (Brahmbhatt \& Christiaensen, 2008)(Dillona \& Barrett, 2013) .Tell that Oil price affect the grain price to these three ways. Firstly as the price increase it will directly effect on the inputs like inert fertilizer and fuel that is required to run the machines for the crops. Secondly cost immovability of food from country to country also increase it includes the transportation cost. Thirdly the indirect relationships of oil and food price like the conversion cost of corn to ethanol also increase.

As the price of food increase the labor price also increases because labor prices are directly proportion to the food and energy price (Belke \& Dreger, 2013). Price of food stability is a most important ingredient the Asian countries. In these countries we mayabsorb those people in the government who have acknowledged about to controlling the price of food and basic necessities. With the price instability social and political stability also affected. Countries can adjust to slow increases in international prices over time even if as a useful issue (Dawe \& PeterTimmer, 2012).Trade-off between inflation and GDP growth has been found for the studied time-series data (Ayyoub, Chaudhry, \& Farooq, 2011). There is optimistic relationship between GDP growth rate and inflation (Mallik \& Chowdhury, 2001) .GDP growth do not influence by worldwide price shocks (Belke \& Dreger, 2013).The quantity of remittances improved a large amount faster than actual worldwide GDP in the developing countries between 2000 and 2005. With the increase of both energy and food, economy can decrease when economy shrink it create negative force in GDP (Martin, 2009). Oil concentrated industries like chemicals and transport also drop with the increase of oil prices. It creates a significant impact on economic growth which 
is measured as GDP elasticity (Timilsina, 2013). Since the 1990s compared to the 1970s and 1980s the impact of oil prices on GDP is a lot weaker. They also terminate those household drivers comparatively than oil price shocks are primarily responsible for explaining US GDP fluctuations (Timilsina, 2013). When interest rate increases it decrease the total demand and also reduce the economy when economy shrink it reduce the service which create bad effect on households (Belke \& Dreger, 2013).

\section{Methodology:}

To investigate the effect food prices and energy prices on macroeconomic variables. Saar countries are selected for the analysis data from 1982 to 2010 is analyzed. Saar countries are selected for the analysis including Pakistan ,India ,Sri Lanka, and Nepal ,Two main economics of the world US and Japan are also analyzed ,variables use in the analysis include Food index ,Fuel index ,GDP ,Exports and Imports, Electricity, Gas and other fuel index is retrieved from data base of international Labor organization .similarly food index include non-alcoholic beverages is also retrieved from international Labor organization. GDP,Export , and import data from world bank is used in the research.Strongly balanced Pennell of six countries from 1982 to 2010 is used .Descriptive statistics of the sample is shown in table 1.from the result of Pennell regression we observethat GDP increase with increase food prices and energy prices. Exports are also found to be statically significant when regressed foodand energy index and Imports are also found to be statically significant when tested against the food and energy index.

$$
\begin{gathered}
G D P=\alpha 1+\beta 1 \text { FoodPrices } \\
\text { Export }=\alpha 2+\beta 2 \text { FoodPrices } \\
\text { Imports }=\alpha 3+\beta 3 \text { FoodPrice } \\
\text { GDP }=\alpha 1+\beta 1 \text { EnergyPrices } \\
\text { Export }=\alpha 2+\beta 2 \text { EnergyPrices } \\
\text { Imports }=\alpha 3+\beta 3 \text { EnergyPrices }
\end{gathered}
$$

\section{Descriptive Statistics}

\section{Table 1}

\begin{tabular}{|l|l|l|l|l|l|}
\hline Variables & observations & Mean & Std. Dev. & Min & Max \\
\hline Food index & 174 & 89.6 & 15.99 & 267.977 & \\
\hline GDP & 174 & 2.18 & 3.60 & 2.40 & 1.50 \\
\hline Export & 174 & 2.38 & 3.91 & 2.50 & 1.84 \\
\hline Import & 174 & 9.81 & 1.29 & 4.51 & 1.70 \\
\hline Energy & 174 & 96.1 & 61.08 & 14.26 & 431.52 \\
\hline
\end{tabular}

Table 2

Independent Food

\begin{tabular}{|l|l|l|l|l|}
\hline Dependent variables & \multicolumn{1}{|c|}{ Coefficient } & Std .Error & $\mathbf{Z}$ & $\mathbf{P}>[\mathbf{Z}]$ \\
\hline GDP & 6.03 & 2.66 & 2.27 & 0.023 \\
\hline Export & 9.18 & 3.53 & 2.60 & 0.009 \\
\hline Import & & & & \\
\hline
\end{tabular}

Table 3

Independent Energy

\begin{tabular}{|l|l|l|l|l|}
\hline Dependent Variables & Coefficient & Std .Error & $\mathbf{Z}$ & $\mathbf{P}>[\mathbf{Z}]$ \\
\hline GDP & & & & \\
\hline Export & 4.84 & 2.02 & 2.40 & 0.016 \\
\hline Import & 7.33 & 2.67 & 2.74 & 0.006 \\
\hline
\end{tabular}




\section{Conclusion:}

The study concludes that macroeconomic variables like GDP,Export, Import,is highly affected by food and oil shocks. As food is the basic need and increase its price will affect most segment of the society, similarly energy price are very important. Thus it is influencing most of the macroeconomic variables.

\section{References:}

[1]. Abbott, P. (2009). Development Dimensions of High Food Prices. 18, 1-98.

[2]. Akpan, E. O., \& Atan, J. A. Effects of Exchange Rate Movements On Economic Growth in Nigeria. CBN Journal of Applied Statistics, 2 (2), 1-14.

[3]. Alfaro, L., Chanda, A., Ozcan, S. K., \& Sayekd, S. (2004). FDI and economic growth: the role of local financial markets. Journal of International Economics, 89-112.

[4]. Alom, F. (2011). Economic Effects of Oil and Food Price Shocks in Asia and Pacific Countries: An Applicationof SVAR Model. 144.

[5]. Alom, F., Ward, B. D., \& Hu, B. (2013). Macroeconomic effects of world oil and food price shocks in Asia and Pacificeconomies: application of SVAR models. 37 (3), 327-372.

[6]. Alom, F., Ward, B., \& Hu, B. (2011). Spillover effects of World oil prices on food prices:evidence for Asia and Pacific countries. 29, 1-29.

[7]. Avalos, F. (2013). Do oil prices drive food prices? 1-28

[8]. Ayyoub, M., Chaudhry, I. S., \& Farooq, F. (2011). Does Inflation Affect Economic Growth?The case of Pakistan. Pakistan Journal of Social Sciences (JPSS), 31 (1), 1-14.

[9]. Bakhat, M., \& Würzburg, K. (2013). Co-integration of Oil and Commodity Prices:. 1-25.

[10]. Bakhat, M., \& Würzburg, K. (2013). Price Relationships of Crude Oil and Food Commodities. 1-23.

[11]. Baumeister, C., \& Kilian, L. (2013). Do Oil Price Increases Cause Higher Food Prices? 1-67.

[12]. Bekkers, E., Brockmeier, M., Francois, J., \& Yang, F. (2013). Pass Through, Food Prices and Food Security. 1-20.

[13]. Belke, A., \& Dreger, C. (2013). The transmission of oil and food prices to consumer prices Evidence for the MENA countries. 1-27.

[14]. Bouët, A., \& Debucquet, D. L. (2010). Economics of Export Taxation in a Context of Food Crisis. 1-32.

[15]. Brahmbhatt, M., \& Christiaensen, L. (2008). Rising Food Prices in East Asia:Challenges and Policy Options. 1-18.

[16]. Capehart, T., \& Richardson, J. (2008). Food Price Inflation: Causes and Impacts. 1-6.

[17]. Cecchetti, S. G., \& Moessner, R. (2008). Commodity prices and inflation dynamics1. 55-66.

[18]. Charnavoki, V., \& Dolado, J. J. (2013). the effects of global shocks on small commodity-exporting economies.lessons from canada. $1-45$.

[19]. Cunado, J. P. (2005). Oil prices, economic activity and inflation:evidence for some Asian countries. 65-83.

[20]. Dawe, D., \& PeterTimmer, c. (2012). Why stable food prices are a good thing:Lessons from stabilizing rice prices in Asia. 127-133.

[21]. Dev, S. M. (2013). Rising food prices in South Asia:A policy framework to mitigate adverse effects. 1-33.

[22]. Dillon, B. M., \& Barret, C. B. (2013). The Impact of World Oil Price Shocks on Maize Prices in East Africa. 1-53.

[23]. Dillona, B. M., \& Barrett, C. B. (2013). The Impact of World Oil Price Shocks on Maize Prices in East Africa. 1-53.

[24]. Freire, C., \& Isgut, A. (2011). High Food and Oil Prices and Their Impact on the Achievement of MDG 1in Asia and the Pacific. 128.

[25]. Ganguly, K., \& Gulati, A. (2013). The political economy of food price policy The case study of India. 1-27.

[26]. Hanson, K., Robinson, S., \& Schluter, G. (1993). Sectoral Effects of a World Oil Price Shock:Economywide Linkages to the Agricultural Sector. Journal ofAgricultural and Resource Economics , 96-116.

[27]. Jones, L. E., \& Manuellib, R. E. (1995). Growth and the effects of inflation. Journal of Economic Dynamics and Control , 14051428.

[28]. Khan, M. A., \& Ahmed, A. (2011). Macroeconomic Effects of Global Food and Oil price Shocks to the Pakistan Economy: A Structural Vector Autoregressive (SVAR) Analysis. 1-26.

[29]. Mallik, G., \& Chowdhury, A. (2001). INFLATION AND ECONOMIC GROWTH: EVIDENCE FROM FOUR SOUTH ASIAN COUNTRIES. Asia-Pacific Development Journal, 8 (1), 123-135.

[30]. Martin, P. (2009). The Recession and Migration:Alternative Scenarios. 1-16.

[31]. Saghaian, S. H. (2010). The Impact of the Oil Sector on Commodity Prices: Correlation or Causation? Journal of Agricultural and Applied Economics , 477-485.

[32]. Sohrabji, N. (2011). Impact of Exchange Rates on Consumer Prices in India:Comparing Different Trade Liberalization and Monetary Policy Regimes. (12), 1-12.

[33]. Thangavelu, S. M., Jiunn, A. B., \& James. (2004). Financial development and economic growth in Australia: An empirical analysis. 247-260.

[34]. Timilsina, G. R. (2013). How Much Does an Increase in Oil Prices Affect the Global Economy? Some Insights from a General Equilibrium Analysis. 1-16.

[35]. Valenzuela, E., v. d., \& Anderson, K. (2009). General equilibrium effects of price distortions on global markets, farm incomes and welfare. 1-60.

[36]. Wakeford, J. J. (2006). The Impact of Oil Price Shocks on the South African Macroeconomy: History and Prospects. 1-29. 